\title{
観測者メタメリズムの等色変動の成因
}

\author{
専門会只 納谷 嘉信* 李門会员 橋本健次郎** \\ 尃門会員高浜幸太郎*** 専門会员 側垣 博明***
}

\section{Causes of Color-Matching Variation on Observer Metamerism}

Yoshinobu Nayatani (Fellow Member)

(Osaka Electro-Communication University)

Kenjiro Hashimoto (Fellow Member)

(Lighting Engineering Development Center, Matsushita Electric

Industrial Co. Ltd.)

Kotaro Takahama (Fellow Member) and Hiroaki Sobagaki (Fellow Member)

(Electrotechnical Laboratory, Osaka Branch)

\begin{abstract}
The purpose of the present study consists of the following two items: (1) to clarify the cause of the significant difference found between the total variation and the estimated change due to age difference of color matches on metameric-sample pairs for color-normal observers from age 20 to 60 studied by P. K. Kaiser et al (Color Res. and Appl. 5 (1980) 65), and (2) to confirm whether the metameric-sample pairs of the Davidson and Hemmendinger (abbreviated by $\mathrm{D} \cdot \mathrm{H}$ ) color rule are representative for assessing the relation between observer and illuminant metamerism index. The former is analyzed by using the $\mathrm{D} \cdot \mathrm{H}$ color-rule samples and the Stiles's 20 color-matching functions. The latter is studied by using the Wyszecki's 12 gray metameric-sample pairs.

Results are summarized as follows: (1) The significant difference between the total variation and the age effect found in the study by P. K. Kaiser et al. is supposed to be caused mainly by the matching errors of their observers in this kind of experiments. (2) The $\mathrm{D} \cdot \mathrm{H}$ color-rule samples can not be representative for determining the relation between observer and illuminant metamerism index. (3) The Stiles's 20 color-matching functions are suitable for assessing observer metamerism on color-normal observers.
\end{abstract}

\section{1. は じめに}

われわれは前報1)で，正常観测者の等色関数に基づく観測老 メタメリズムに打ける年秢效果と, 多数の実観測者および Davidson and Hemmendinger のカラールール (以下, D・H カラー ルールと呼ぶ）を用いた Kaiserら ${ }^{2)}$, および Billmeyerら ${ }^{3)}$ の同 一の効果の予測との一致の程度を確認するため, Stiles による20 人の等色関数 ${ }^{4}$ に基ついて検討した. その結果, 两者は矛盾せず ほぼ一致することを明らかにした。これに基ついて, Stiles によ る20人の等色関数群が，20～60藏の年龄籍囲を含む正常観测者群 の良好な代表であることが確認された。すなわち Stiles による 20 人の観測者は，一般に若年観測者の代表などといわれている が，とれは䜋まりであることが明らかになった。しかし，なお次 の問題が残されていた。

* 大阪䉓気通信大学工学部

** 松下電器産業秘技術本部照明技術開発センタ一

*** 電子技術総合研究所大阪支所
一つは, 前報1) 表 1 に示したように, 类钼測者の等色変動の範盲 が彼らの単位である Total Score****で11単位であるのに対し， 条件等色変動の年龄効果（20～60歳の年柃変化に対する平均等色 点の変位) は 4.5 単位であった。この雨者の大きい差の原图の究 明がさらに望まれる．この点については，Kaiser らもをて検 討の重要性を指摘している. 他の一つは前解1) 表 1 に示した光メ タメリズム指数と, 観測者メタメリズム指数との閘係を評価する 条件等色サンプル対の妥当性に関する問題である。闹報1表 1 の 結果は, Kaiser ら抢よび Billmeyer らが用いた D・H カラール ール・サンプル群について求めたものである．D・H カラールー ル・サンプルの 2 系列，それぞれ 21 サンプル異なる分光反射率 分布を有する. しかし各系列内では相互に分布の類似性が高く, 実質的には 1 種類の条件等色対と考光られる.一般に上述の $\mathrm{D} \cdot \mathrm{H}$ カラールール・サンプルで求めた光メタメリズム指数と, 観測者 メタメリズム指数の比 $8.0: 0.87$ が，そのサンプル群と異なる分

**** Total Score の算出方法については前報の脚注参照 
光特性を有する他の条件等色サンプル対に対しても，成立するか ぞらか明らかではない.つまり, 光メタメリズム指数と観測者メ タメリズム指数の関連を論ずるのに, D・H カラールールの条件 等色サンプルが果たして代表性があるのかという問題である。

本論文は，これらの問題を明らかにすることを目的としたもの であり，20～60藏の年秢筈囲を含む正常観测者群の代表として は，前報 ${ }^{1)}$ の結果を考虑して Stiles の 20 人の等色関数を用いる こととした。

\section{2. 正常観測者の等色变動の範囲について}

Kaiser らの実観测者の $\mathrm{D} \cdot \mathrm{H}$ カラールールを用いる等色判定 実験結果は, 彼らの単位である Total Score で示されている. その数値は, 星光一白熱光間の平均等色点の変位 16 単位, $20 \sim 60$ 歳の正常観测者の等色变動の範囲11単位，年粭の变化による平均 等色点の変位 4.5 単位であった（前報1) 表 1 参照).ここで以下 の説明をわかりやすくするため，観測者メタメリズムに関連する 諸量の定義を簡単に述べる.

Kaiser ら ${ }^{2)}$ の $\mathrm{D} \cdot \mathrm{H}$ カラールール・サンプルの多数の観測者 の等色点（Total Score で表わす）を，観测者の年秢に対して置 点したものの模式図を図 1 に示す (Kaiser ら²) Fig. 4 に対 応).

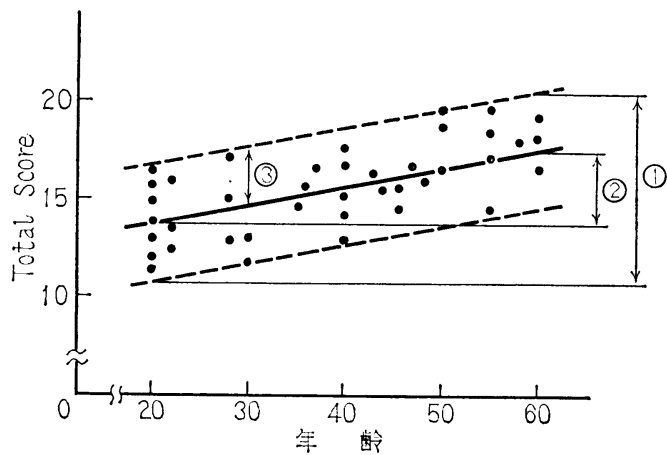

図 1 多数の钼测者の年䁬々等色点 (Total Score で 表わす)の関数走示す模式间

図 1 は年秢20〜60藏を横軸に, Total Score を綎軸に置点した ものである. 図1の中央の垁線は年柃と Total Score の回帰直 線を示す. 回帰直線の上下にそれぞれ回㷌直線と平行に引かれた 破線の 2 直線は, 回㷌直線の上下に散布する Total Score の存 在範囲を示す（現実には実験䛊差を含むために，回帰直線からの 変動は個々の年龄により異なる). 図 1 に抋いて(1)で示す籁囲は, 20〜60歳の正常観測者の Total Score の变動の全範囲であり,

これを以下正常観測者の等色変動の籁囲と呼ぶ. (2)で示す变動は 回㷌による変動であり, 年粭の変化による平均等色点の変位ある いは単に年秢効果ともいう. (3)で示す距離は回㷌からの変動であ り, 年秢効果以外に後述の 3 要因からなる変動に対応する. この 回帰からの変動（ほぼ Total Score で 5.3 単位）が，年秢效果 (Total Score で 4.5 単位) に加わり, 結果的に大きな変動の範 囲 (Total Score で11単位) として現われている。

本節では，この年秢による平均等色点の变位 4.5 単位に比べ, 正常観測者の等色変動の範囲11単位とかなり大きくなる原因, 寸 なわち回帰からの変動の原因について究明する。

まず回帰からの変動のかなり大きくなる原因として, 主に次の 三つが考えられる。

（1）年齢とともに進行する 水晶体の黄色化の 程度が, 同一年
秢において变動すること.すなわち, 同一年柃であっても黄色化 の進んでいる人と遅れている人が存在する場合, 観測者の年柃と Total Score の置点は, 当然のことながら回帰からの変動として 現われる。

（2）水晶体の黄色化以外の視覚の生理学的原因による等色関数 の個人間変動による影響が存在すること．たとえば，黄斑部の着 色の程度の個人差などが存在するとすれば，水晶体の同一黄色化 状態においても等色関数の個人差を生じ，同一年龄でも等色点の 差違が起こる.この結果, 回帰からの変動を生ずる。

(3) $\mathrm{D} \cdot \mathrm{H}$ カラールールの条件等色の個人ごとの判定䛊差によ る影響の存在すること. D・H カラールールの各サンプルの色度 は不連続的に変化している。また観測者の判定条件も視感色彩計 に括ける等色判定ほどには条件が固定されていないと思われる. また多数の観測者を用いるため，観測者によっては判定䛊差の大 きい人も存在するかもしれない。これらはいずれも回帰からの変 動を与える.

以上の回帰からの変動に対する 3 要因による影響を論ずるた め, D・H カラールールのサンプル群，および Stiles による20人 の等色関数を用いて，Kaiser らの正常観测者の等色変動の範囲 に対応するものを求め比較することがよいと考えた，との理由は 次のようである.

(1) Stiles の20人の等色関数は, 20 60歳の正常観湘者群を代 表すると考えられること.

() Stiles の等色関数群は20〜60歳の正常観測者について，上 記(1)項の水晶体の黄色化, および(2)項のそれ以外の視覚生理学的 要因のすべてを含んでいること.

(㚈等色関数を用いる反射物体の三刺激値の予測は，一種の重 みつき平均であるため，等色関数の各波長ごとの測定䛊差がかり に Kaiser らの判定㖣差と同程度であっても, 三刺激值の予测精 度はかなり改善されること。

$\Leftrightarrow$ このため, Stiles の 20 人の個々の等色関数ごとに $\mathrm{D} \cdot \mathrm{H}$ 力 ラールール・サンプル群の等色点を定め, その Total Score を 求め 20 人の等色変動の範囲を求めることは, 回帰による変動に対 する要因(1)，(2)を主として反映する，したがって，Kaiser らの 結果との比較は要因(3)の判定誤差の程度の手がかりを与えよう.

表 1 Stiles による20人の储々の等色関数にもとで等色となる $\mathrm{D} \cdot \mathrm{H}$ カラールールサンプル対と Total Score の伯 (照明光: $\mathrm{D}_{65}$ )

\begin{tabular}{|c|c|c|c|}
\hline \multicolumn{2}{|c|}{ 䭒 测 者 (作龄) } & 等色サンプル刘 & Total Score \\
\hline JSP & $(50)$ & $6.9, E-7$ & 12.6 \\
\hline $\mathrm{W}$ & (29) & $5.9, \mathrm{D}-4$ & 10.3 \\
\hline GEVL & (49) & 7. $3, F-2$ & 13.5 \\
\hline EMK & (27) & $6.4, \mathrm{D}-5$ & 10.9 \\
\hline WSS & (54) & $6.7, \mathrm{E}-7$ & 12.4 \\
\hline JMB & (30) & $6.5, D-9$ & 11.4 \\
\hline DLT & (50) & $6.6, \mathrm{E}-3$ & 11.9 \\
\hline $\mathrm{MCB}$ & (27) & $6.1, D-6$ & 10.7 \\
\hline JAR & (22) & $5.4, C-9$ & 9.3 \\
\hline MG & (22) & $5.9, \mathrm{D}-3$ & 10.2 \\
\hline PSW & (31) & $6.1, D-6$ & 10.7 \\
\hline FJJC & (22) & $6.1, D-4$ & 10.5 \\
\hline EA & (28) & 6. 7, $\mathrm{E}-2$ & 11.9 \\
\hline RNW & (28) & $6.3, \mathrm{D}-6$ & 10.9 \\
\hline MHP & (44) & $6.8, E-5$ & 12.3 \\
\hline WDW & (50) & $6.8, E-5$ & 12.3 \\
\hline GW & (34) & $6.5, \mathrm{D}-9$ & 11.4 \\
\hline DBJ & (59) & 7. $4, \mathrm{G}-2$ & 14.6 \\
\hline EML & (34) & $6.7, \mathrm{E}-4$ & 12.1 \\
\hline JMB & (31) & $6.6, D-9$ & 11.5 \\
\hline
\end{tabular}


観測者メタメリズムの等色変動の成因 専門会員 納谷, 橋本, 高浜, 側垣

以下, 次の手順で計算を行なった。

まず, Stiles の 20 人の個々の等色関数ごとに標準の光 $\mathrm{D}_{65}$ の照 明下で，ほぼ等色となる D・H カラールール・サンプル対をそれ ぞれ計算と補問により定めた. そその結果を表 1 の第 2 列に示 している.たとえば, 観測者 JSP はについては 6.9 抢よび E-7 と示されている. 前者は, 数字サンプル系列 6 と 7 のサンプルに 対し, 両方の色度点間の距離を $9: 1$ の比にわける点を示す. 後 者は, 文字系列で $\mathrm{E}$ と $\mathrm{F}$ 色度点間の距離を $7: 3$ にわける点に 条件等色の交点があることを示す.

次に, Kaiser らの実観測者による等色判定実験結果との対応 をはかるために，等色となる $\mathrm{D} \cdot \mathrm{H}$ カラールール・サンプル対に ついて，Kaiser らが用いた Total Score を算出した. 上述の観 测者 JSP の場合, E-7 は5.7 と表わされるので, Total Score は6. $9+5.7=12.6$ と与えられる.

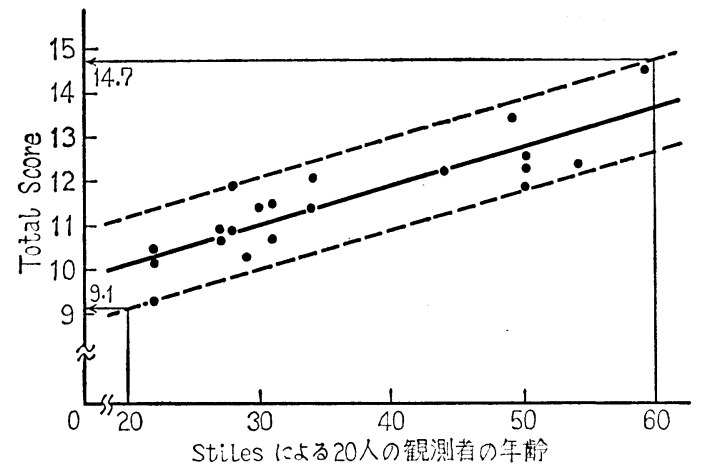

図 2 Stilesによる 20人の観測者の年䏩と Total Score の関係

表 1 の第 3 列に, Stiles の 20 人の個々の等色関数下で等色とな る $\mathrm{D} \cdot \mathrm{H}$ カラールール・サンプル対に対する Total Score の值 を示す. 図 2 は表 1 の結果に基ついて Stiles の 20 人の個々の観 測者の年龄と Total Score の関係を示したものである. 図 2 よ り観測者の年齢と Total Score との間には高い相関（相関係数 $r=0.87)$ があることがわかる. 図 2 に示す実線は年齢と Total Scoreの回㷌值線を示し, 破線はこれと平行に定めたTotal Score のばらつきの最大と最小の範囲を近似的に示す直線である.

図 2 より，観測者の年秢の変化(20６0歳)による Total Score の変化は約 3.6 単位である. この值は, 図 2 に示す回帰直線 $(y$ $=0.0895 x+8.343)$ に $x=20$ および60の值を代入し, Total Score の $y$ の值をそれぞれ求めた值13.71，および10.13の差に等 しい.この 3.6 単位は, Kaiser らの実験結果の示す観測者 タ メリズムの年秢による平均等色点の変位 (年齢効果; 4.5 単位) にほぼ近似している．また回帰直線からの Total Score の変動 は, 回帰直線と平行に 示した上下 2 本の 点線の 範囲の $1 / 2$ であ り, 約 1.0 単位である. Kaiser らの実験結果では, 因 2 と同様 の図 (文献2)の Fig 4) に拈ける Total Score の回㷌直線からの 変動（図 1 の(3に対応）を求めれば, 約 5.3 単位となる. また, Kaiser らの正常観測者の等色変動の範囲11単位に対応して, 四 2 より, 60歳の年㱓に相当する Total Score の最大值 14.7 単位 と20歳の年柃に相当する Total Score の最小值 9.1 単位より 5.6 単位 (14.7-9.1) の Total Score の值を得る.

表 2 は, D·H カラールール・サンプルについて, Stiles の20 人の個々の等色関数に基づいて求めた観測者の 年踰变化による Total Score の変化 (条件等色変動の 年齢効果), Total Score
表 2 Stiles の20人の等色関数に基つく等色変動の範囲と, Kaiser らの夷観測者に基づく等色変轩の笵囲との比較

\begin{tabular}{|c|c|c|}
\hline & 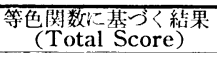 & 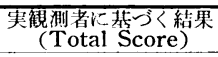 \\
\hline 条件等色变動の年脚刘果 & 3.6 & 4.5 \\
\hline $\begin{array}{l}\text { Total Score } \text { の回㷌直線 } \\
\text { からの変動 }\end{array}$ & 1.0 & 5.3 \\
\hline 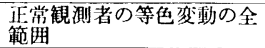 & 5.6 & 11 \\
\hline
\end{tabular}

の回㷌直線からの変動，および正常観測者の等色変動の全範囲を 示す.さらに同表には Kaiser らの実観測者に対する等色判定実 験に基づくそれぞれの対応する結果をあわせて示してある. 表 2 において，等色関数から求めた結果と Kaiser らの結果と比較す ると，まず年秢効果が両者でほぼ等しいことがわかる. しかし， 前述の議論からも想像されるように, 回帰直線からの変動および 正常観測者の等色変動の全範囲については, Stiles の等色関数に 基づく予測は Kaiser らの結果に比べてかなり小さい.

さて, 上述の等色関数に基づく等色変動の範囲 (Total Scor で 5.6 単位) は, 観測者の視覚系のスペクトル感度の個人変動 （回帰からの変動要因 (1)，(2)を含む）に関するものである. 一 方，Kaiser らのそれに対応する実観测者の等色変動の範囲（To， tal Score で11単位) は，等色関数を用いる場合に比べさらに判 定䛊差（回帰からの変動要因(3)）が加わったものと推測される. このことは, Billmeyer らの実験においても同様と思われる。 れらの数值は, 同一の $\mathrm{D} \cdot \mathrm{H}$ カラールール・サンプルを用いての 結論であるので, 両者の差 5.4 単位 (11-5.6) が Kaiser らの 実験の観測者の判定䛊差に対応するものと推测される.

一般に，実サンプルを用いる等色判定に比へ，等色関数を用い る色度計算，および条件等色の判定サンプルの決定は，既述の上 らに精度が良いと思われる．仮りに，等色関数の測定精度が各波 長ごとに実サンプルの等色判定精度と同一と考えた場合，等色関

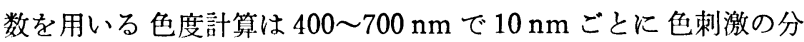
光特性を等色関数により重みづけ加算を行なう。これは一種の平 均過程とみなせるので, 前者の精度に比べ後者の精度は高いと考 えられる.ささに等色関数は测定上三次元調整により原理的に完 全なカラーマッチングが可能であるのに対 し， D・H カラールー ルは二次元調整であり，完全にはカラーマッチングしない色の類 似判断のため, D・H カラールールによる等色判断は精度が低い と考えられる. この意味で Kaiser らおよび Billmeyer らの約 20〜60歳にわたる正常観測者の等色変動の範囲は, Stiles による 20 人の等色関数を用いる場合に比へ，判定誤差の存在のためやや 大きく見積もっていることが考えられる.

すなわち，本節の解析より明らかなように， Stiles の 20 人の等 色関数を用いる観測者メタメリズム指数の評価は, Kaiser らある いはBillmeyerらの結果と背離するものではない。むしろ, 後者 から，本来原理的に存在することが望ましくない判定誤差を除い たものであって，観測者メタメリズムの効果を純粋に評価するに は好適であると考兄られる，さらに Kaiser ら拈よび Billmeyer らの方式で, 等色変動の範囲を観測者メタメリズム指数とすると, 若年秢扣よび老年㱓者の突出した判定誤美が，結果の変動に大き く影響を与える.このため安定な評価指数をらることは困難であ る.

\section{3. 観測者メタメリズムの評価に要する条件等色サン プルの種類 (次元性)}

われわれは，すでに D・H カラールール・サンプルについて光 
メタメリズム指数と平均観測者メタメリズム指数, および条件等 色変動の年龄効果の定量的関係を明らかにしている (湔報 ${ }^{1}$ 表 4 参照).それぞれ色庤で8.00:0.87:2.5である. しかし，これら の関係は，D・H カラールール・サンブルといら先睤的に一組の 条件等色サンプル対について成立することである。その他の分光 特性の界なる条件筞色サンプル対に対して，果たして同一の数量 的関係が成立するかどらかは明らかでない，つまり，光メタメリ ズム指数と観測者メタメリズムに関する指数との定量的評価を行 なら場合，D・H カラールール・サンプルだけで十分なのか，それ とも，その他の条件等色サンプル対を付加する必要があるかは， いまだ明らかでない，したがって光メタメリズム指数と観测者メ タメリズム指数の関連に関する定量的関係を把握するためには, 最低何種類の条件等色サンプル対が必要であるかを明らかにする 必要がある.このため, Wyszecki らの12条件等色サンプル群 ${ }^{5)}$ のそれぞれと $\mathrm{D}_{65}$ ，および CIE 1931標準観测者に関して条件等 色をなす一定の平担反射率のサンプルからなる 12 対の灰色条件等 色サンプル対6)を用いて検討した。

12 対の灰色条件等色サンプル対は, 分光反射率が可視域で一定 （反射率=0.3）の灰色と $\mathrm{D}_{65}$ 光, CIE 1931 標準観测者に関して 条件等色となるように，無限個の条件等色サンプル群への代表性 を考虑してそれぞれ理論的に合成され求められたものであり，反 射特性の起伏の大きいものから小さいものまで, 様々のむのを包 含している.これらの灰色条件等色サンプル対を用いて，照明光 の変化 $\left(\mathrm{D}_{65}\right.$ 光から $\mathrm{A}$ 光に変化した塨命 $)$ にる光メタメリズム指 数, 平均観测者メタメリズム指数, お上び条件等色変動の年䏩効 果を算出した，各灰色条件等色サンプル対に対与る平均観测者 タメリズム指数の算出は, 前報1)の3.2.2 節で述べた方法と同様 である.すなわち $\mathrm{D}_{65}$ 光，CIE 1964 補助標準推测者を其準とした 条件等色サンプル対に対し, 観測者を納谷・高浜ら の)最滴化偏 差関数を CIE 1964 補助標隻钼測者に加兄た等色関数に変更した 場合の色差を求める方法をとった，李た条件等色変動の年踰効果 に関する色差の算出も，前報の 3.2.1 節で述べた方法を用い, 20

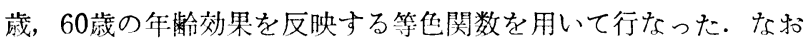
観測者として，CIE 1931標準観测者の代わりに CIE 1964補助標 準観測者を用いたために生じる各サンプルの残存色差は，ゼロと なるように乘法的補正を施した。

表 3 K, 12対の灰色条件等色サンプル対に対する平均観测者 メタメリズム指数, 条件等色変動の年軨効果の色差, 光メタメリ ズム指数の計算結果を示す. さらに表 4 には平均観測者メタメ リズム指数と光メタメリズム指数の相対関係を示すために，条件 等色変動の年䑪効果の色差を 1.0 亿基蕉化した場合の冬色差の相

表 3 12対の灰色条作等色サンプルを用いた場合の，可均

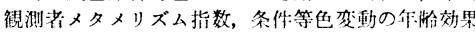
の出羔，光メタメリズム指数の䦛保

\begin{tabular}{|c|c|c|c|}
\hline $\begin{array}{l}\text { 条件等臽 } \\
\text { サンプル対 }\end{array}$ & $\begin{array}{l}\text { 平焦䘽测考メタメリ } \\
\text { ズム指数 }\end{array}$ & 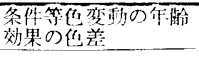 & $\begin{array}{l}\text { 光メタメリズ久指数 } \\
\text { (D65 光一A光间) }\end{array}$ \\
\hline 1 & 2. 36 & 5.94 & 21.55 \\
\hline 2 & 0.49 & 0.95 & 2.88 \\
\hline 3 & 0.91 & 2.24 & 9.21 \\
\hline 4 & 1.65 & 4. 96 & 10.65 \\
\hline 5 & 1.65 & 4.60 & 7.62 \\
\hline 6 & 1. 20 & 2.86 & 12.41 \\
\hline 7 & 0.50 & 1. 37 & 1. 27 \\
\hline 8 & 1. 37 & 3. 53 & 10.62 \\
\hline 9 & 0.62 & 1.32 & 6. 48 \\
\hline 10 & 1.11 & 2.88 & 4. 06 \\
\hline 11 & 1.53 & 3. 64 & 16.05 \\
\hline 12 & 2.55 & 6.43 & 16.59 \\
\hline
\end{tabular}

表 4 表 3 に示した各色差の相対优

\begin{tabular}{|c|c|c|c|}
\hline $\begin{array}{l}\text { 条件等魚 } \\
\text { サンプル効 }\end{array}$ & 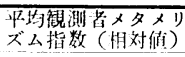 & 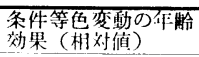 & $\begin{array}{c}\text { 光メタメリズム指数 } \\
\text { (相奶值) }\end{array}$ \\
\hline 1 & 0.40 & 1.00 & 3.63 \\
\hline 2 & 0.52 & 1.00 & 3.03 \\
\hline 3 & 0.41 & 1.00 & 4. 11 \\
\hline 4 & 0.33 & 1.00 & 2.15 \\
\hline 5 & 0.36 & 1.00 & 1.66 \\
\hline 6 & 0.42 & 1.00 & 4.34 \\
\hline 7 & 0.36 & 1.00 & 0.93 \\
\hline 8 & 0.39 & 1.00 & 3. 01 \\
\hline 9 & 0.47 & 1.00 & 4.91 \\
\hline 10 & 0.39 & 1.00 & 1.41 \\
\hline 11 & 0.42 & 1.00 & 4. 41 \\
\hline 12 & 0.40 & 1.00 & 2.58 \\
\hline 雨 & 0.41 & 1.00 & 3.01 \\
\hline
\end{tabular}

対值を示す.

表 3, 表 4 より, 観測者メタメリズムと光メタメリズムの関係 は各サンプル対に対して異なり, 必ずしも一定ではないことがわ かる. 表 4 に打いて平均観測者メタメリズム指数は平均值 0.41 , 最大 0.52 , 最小 0.33 であり, 平均值 0.41 に対する相対\%は 127 $80 \%(127 / 80 \simeq 1.6$ 倍）の範囲である. 等色変動の年路効果に対 して基準化されているので, 年齡効果のサンプル対間変動をも上 記の $127 \sim 80 \%$ の変動範囲に含まれることを考虑すると, 平均観 測者メタメリズム指数と年齢効果の関係は, ほぼ使用する条件等 色サンプル対に無関係と考えてよい。

一方, 光メタメリズム指数に関しては, 表 4 より平均 3.01 , 最 大 4.91 , 最小 0.93 であり, 平均值3.01飞対する相対\%は163〜31 \% (163/31 〜5. 3倍） と大きく変動する. すなわち，光メタメリ ズム指数と観测者メタメリズムに関过する評価指数との比は, 使 用する条件等色サンプルの種類により，大きく变動することがわ かる.

なお，12条件等色サンプル対に対する表 4 の下段に示す平均值 は, 平均観測者メタメリズム指数が $\mathrm{D}_{65}$ 光一 $\mathrm{A}$ 光間の光メタメリ ズム指数の約 $1 / 7$ であることを示している.この約 $1 / 7$ という楛 は, 前報1) で報告した $\mathrm{D} \cdot \mathrm{H}$ カラールール・サンプルに対する結 果 (平均観测者メタメリズム指数 /光メタメリズム指数 $=\frac{0.87}{8.00} \doteqdot$ $\frac{1}{9}$, 前報表 4 参照）とは異なっている. この差は, D・H カラー ルール・サンプルに対する光メタメリズム指数 (8.00単位) が, 照明光を $\mathrm{D}_{65}$ 光から $\mathrm{A}$ 光に変化させた場合の光メタメリズム指数 (6.9単位) と, 照明光を $\mathrm{A}$ 光から $\mathrm{D}_{65}$ 光に変化させた場合の光メ タメリズム指数 (9.1 単位) の 2 方向の色差の平均值であるのに 対し, 上述の 12 灰色条件等色サンプル対に対する光メタメリズム 指数は, $\mathrm{D}_{65}$ 光から $\mathrm{A}$ 光に変化させた場合の 1 方向の色差の值に 基づいているからである. $\mathrm{D} \cdot \mathrm{H}$ カラールール・サンプルについ て, 照明光を $\mathrm{D}_{65}$ 光から $\mathrm{A}$ 光に変化させた場合の光メタメリズム 指数 (6.9 単位) に対する平均観測者メタメリズム指数 (0.87単 位) の比は約 $1 / 8$ で, 12灰色条件等色サンプル対に対する結果に 近い.

さて日的は, 光メタメリズム指数と観測者メタメリズムに関す る評価指数の関係を定めるのに必要な条件等色サンプル対の種類 である、これを明確にするため, 表 3 の結果を 図 3 のようにプ ロットした. 困 3 で横軸は平均観測者メタメリズム指数, 縦軸は 光メタメリズム指数である. 一印は12条件等色サンプル対の各々 の置点結果であり, O印は $\mathrm{D}_{65}$ 光, CIE 1964補助標準観測者のも とで等色となる一対の $\mathrm{D} \cdot \mathrm{H}$ カラールール・サンプル（No. 6, No. E) に対する同様の計算結果である. ただし， D・H カラー 


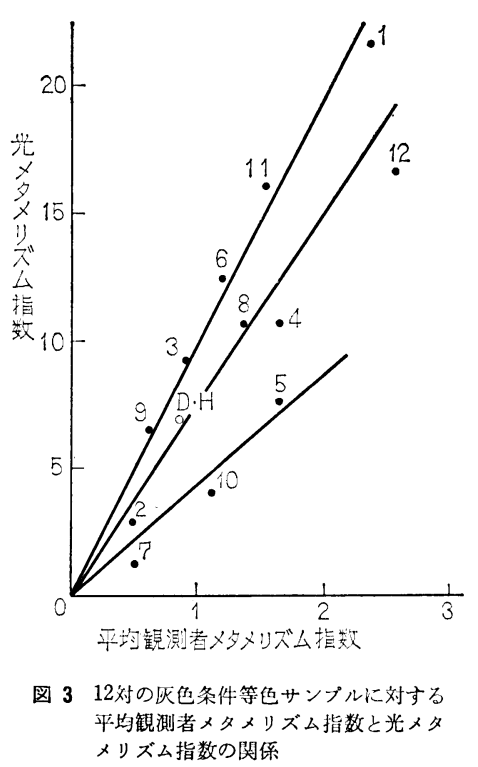

ルール・サンプル対（No. 6, No. E) についての光メタメリズ 么の色差は, 照明光に $\mathrm{D}_{65}$ 光から $\mathrm{A}$ 光に変化させた場合, 特よび $\mathrm{A}$ 光から $\mathrm{D}_{65}$ 光に变化させた場合の各色差值 (それぞれ6.9単位, 9.1 単位, CIELAB 色差公式使用) の平均値 (8.0 単位) を用い ずに, 前者の照明光を $\mathrm{D}_{65}$ 光から $\mathrm{A}$ 光に变化させた場合の色差值 （6.9単位）を用いた。

図 3 を視察すると, 各点は 3 種の直線の近傍に表わされる 3 グ ループに分けられる.すなわち，3直線ごとに平均観測者メタメ リズム指数 1 単位に対し，それぞれ光メタメリズム指数約 4,7 , 10単位であることが，それぞれ3本の直線より読み取ることがで きる.つまり，光メタメリズム指数と平均観測者メタメリズム指 数の関係は, 使用する条件等色サンプル対に関する依存性があ り，一意に定まらないことがわかるすすなわち光メタメリズム指 数と平均観測者メタメリズム指数の大きさの相対関係は, 使用す るサンプル対の種類によって異なる.すなわち $\mathrm{D} \cdot \mathrm{H}$ カラールー ル・サンプルを用いて定めた光メタメリズム指数と, 観測者メタ メリズム指数の Kaiser ら括よび Billmeyer らの比較結果は, もし使用する条件等色サンプル対を変更すると異なる結論をうる 可能性のあることが推測される.

\section{4. 結 論}

Kaiser らの実観測者の等色変動の範曲11単位が，年路の变化 による平均等色点の変位 4.5 単位に比べ，かなり大きくなる原因
を明らかにするために, Kaiser らの用いた D・H カラールー ル・サンプル群拉よび Stiles の 20 人の等色関数を用いて検討し た.さらに, 光メタメリズム指数と観測者メタメリズム指数の定 量的関係を論ずるのに， D・H カラールールの条件等色サンプル が果たして代表性があるのかどらかを Wyszeeki らの 12 条件等 色サンプル群 ${ }^{5)}$ を用いて検討した. その結果, 次のことが明らか になった

（1）Kaiser および Billmeyer らが報じた正常観測者の条件 等色変動の範囲が，年龄の変化に対する平均等色点の変位（年龄 効果）に比べかなり大きくなる主要な原因は，実観測者による等 色判定実験の判定誤差に起因するところが大きい.

（2）光メタメリズム指数と観測者メタメリズム指数の定量的関 係は，使用する条件等色サンプル対によって異なり一意に定まら ない、したがって, Kaiser らおよび Billmeyer らの D・H カラ ールール・サンプルに基づく光メタメリズム指数と, 観測者メタ メリズム指数の結果も，使用与る条件等色サンプル対によって異 なる結論を得る可能性があると考えられる.

(3) 観測者メタメリズムの評価に対しては, Stiles の 20 人の等 色関数は十分に代表性がある.ささらにこれから求めた納谷ら 偏差観測者は，観测者メタメリズムの評価に好適であると考えら れる. TC-1.3 での採択が期待される.

最後に, Stiles の 20 人の等色関数の年秢情報をご提供いただい た富士フィルム株式会社足柄研究所の大田登博士，ならびに観測 者メタメリズムに関する計算解析について，多大な協力をいただ いた大阪電気通信大学学生, 津守康宏, 中尾稔雨君に厚く謝意を 表します。

\section{参 考 文 献}

(1) 納谷，橋本，高浜，侧坦：観測者メタメリズムの年齢効 果, 照学誌 67 (昭58) 520

(2) Kaiser, P. K. and Hemmendinger, H.: Color Res. and 4. Appl. 5 (1980) 65

(3) Billmeyer, F. W. and Saltzman, M.: Color Res. and Appl. 5 (1980) 72

(4) Wyszecki, G. and Stiles, W. S.: Color Science, Wiley (1967) 430

(5) Wyszecki, G.: Acta Chromatica 1 (1962) 1

(6) 高浜, 納谷: 照学誌 56 (昭47) 315

(7) Nayatani, Y., Takahama, K. and Sobagaki, H.: Color Res. and Appl. 8 (1983) 47

（受付1983年 4 月28日） 